\title{
Self and Language Anxiety
}

\author{
Yi-Wen Huang ${ }^{1}$ \\ ${ }^{1}$ Division of Arts \& Sciences, University of New Mexico-Gallup, Gallup, NM, USA \\ Correspondence: Yi-Wen Huang, 705 Gurley Ave. Gallup, NM 87301, USA. Tel: 505-863-7500. E-mail: \\ yhuang75@unm.edu
}

Received: March 23, 2014 Accepted: April 29, 2014 Online Published: May 27, 2014

doi:10.5539/ells.v4n2p66 URL: http://dx.doi.org/10.5539/ells.v4n2p66

\begin{abstract}
This paper discusses relationships between language anxiety and self. Self refers to an individual's (a) self-confidence, (b) language ego, L2/FL self or identity developed during second or foreign language learning, or a combination of both L1 self and L2/FL self. Based on previous literature on language anxiety and L2 or FL learning, language learners' self-confidence might imply a lack of language anxiety which enhances language achievement (e.g., Casado \& Dereshiwsky, 2004; Clément, 1980; Liu \& Chen, 2013; Matsuda \& Gobel, 2004; Onwuegbuzie, Bailey, \& Daley, 1999; Peng \& Woodrow, 2010; Ro, 2013). Language anxiety is an experience unique to the language learning process, and this unique emotion or experience may be associated with the anxiety of feeling limited, broken, incompetent, having another self or a different personality in a target language. I believe that while learning target languages, L2 or FL identities are developing, and L1 identities are reconstructed. Language learners may feel the loss of L1 identities in a target language context or may feel that they are not able to express their thoughts in a target language. When learners feel the loss of L1 identities, feel limited or broken, this may be language anxiety arising.
\end{abstract}

Keywords: identity, language anxiety, self, self-confidence

\section{Introduction}

According to previous literature on language anxiety (e.g., Clément, 1980; MacIntyre \& Gardner, 1991), I believe that language anxiety relates to a learner's self which may consist of (a) self-confidence, (b) language ego, L1 self, or L2/FL self or identity, or a combination of both L1 and L2/FL identity. In this paper, I will discuss the relationships between self and language anxiety. Markus and Kitayama (1991) claimed that universal aspects of the self are referred to as the physical (body), the ecological (environment) self, or the inner/ private (unshared feelings or emotions) self. I believe that for second or foreign language learners, self may be divided into two variables: (a) self-confidence, (b) language ego, L1 self, or L2/FL identity, or a combination of both L1 and L2/FL self. First of all, I will define language anxiety, and later, I will explain its relationships to self-confidence and language identity.

\section{Defining Language Anxiety}

Language anxiety has been defined as an anxiety related to target language learning, the reaction or emotion of general anxieties, or simply associated with social or certain situations while learning the target language. Horwitz, Horwitz, and Cope (1986) defined language anxiety as either a unique experience while learning the target language or the manifestation of other general types of anxiety. For example, shy students might be afraid of public speaking in the target language, and test anxious students might experience the anxiety while being tested in the target language. Their theory of foreign language classroom anxiety consisted of three elements: communicative apprehension, fear of negative evaluation, and test anxiety. MacIntyre (1995) defined language anxiety as a social anxiety, which a learner might have experienced this anxiety in specific social situations, such as speaking in front of a group of people. Similarly, Pappamihiel (2002) described language anxiety as social anxiety, and this anxiety is associated with learners' interaction with target language speakers in class. Likewise, MacIntyre and Gardner (1991) defined language anxiety as a situation-specific anxiety, in which learners might continue to experience the same anxiety in specific situations over time. In the past decade or so, studies on language anxiety have developed a focus on specific language skills-related anxiety such as speaking (Öztürk \& Gürbüz, 2014; Woodrow, 2006), reading (Aydın \& Gönen, 2012; Matsuda \& Gobel, 2004; Ro, 2013), writing (Scullin \& Baron, 2013; Cheng, Horwitz, \& Schallert, 1999; Leki, 1999), and listening (Vogely, 1999; Chang, 2008) in a target language. 


\section{Self-Confidence}

Self-confidence plays a significant role in students' language anxiety and FL or SL language learning. Anxiety and self-confidence might have a negative relationship. Daly, Caughlin, and Stafford (1997) found highly anxious individuals generally have lower self-confidence compared to less anxious people. Similarly, Clément's (1980) integrative motivation model emphasized that self-confidence signifies a lack of anxiety and is an important factor to learning a second language. I agree with Clément's theory that a highly confident language learner who has experienced language anxiety will learn the target language better than a less confident one who has experienced the anxiety because self-confidence (the lack of anxiety) affects students' attitudes or motivation towards learning a target language in academic settings or in target language communities.

I very much agree that self-confidence greatly influences a student's second or foreign language achievement and might lower learners' language anxiety by affecting their attitudes and motivations towards learning the target language and culture. Clément's (1980) model suggested that self-confidence as a secondary motivation leads learners to pursue or take part in interactions in the target language community. Also, the frequency and quality of interaction between the students and the target language community affect their self-confidence; therefore, this self-confidence and motivation predicts their language achievement. This belief is similar to the findings of Selltiz, Christ, Havel, and Cook's (1963) study that foreign students' ratings of the target language group (i.e., attitudes) affect their adjustment and language achievement in the target language community. Foreign students' attitudes toward the target language group and culture might be associated with the frequency or quality of the interaction with the local people or the students who speak English as their native language. The frequency or the quality of the interaction between foreign students and American students might lead them to develop more confidence in English and better language proficiency. In addition, this self-confidence might boost foreign students' attitudes or motivation to frequently interact with the target language speakers. Therefore, this self-confidence might help to improve their language achievement and adjustment when studying in a foreign country.

According to previous studies, relationships exist between language anxiety and either FL or L2 achievement or performance. In previous studies, language anxiety might have a negative relationship with language performance or achievement (e.g., Matsuda \& Gobel, 2004; Ro, 2013). In Onwuegbuzie, Bailey, and Daley's (2000) study, students' perceptions of their own ability, intelligence, and academic competence (high or low self-confidence vs. language anxiety) were associated with language performance. Their results are the same as Ehrman and Oxford's (1995) findings that students' self-perceptions of their academic and foreign language competence (high or low self-confidence) significantly affected their foreign language achievement.

Other studies also support the belief that self-confidence is an important factor for successful language learning (e.g., Casado \& Dereshiwsky, 2004; Ehrman \& Oxford, 1995; Matsuda \& Gobel, 2004; Onwuegbuzie, Bailey, \& Daley, 1999, 2000; Ro, 2013). For instance, Matsuda and Gobel's (2004) research on language anxiety and performance in the foreign language classroom reported that self-confidence is an important factor in language performance in the classroom of first-year college students in Japan. In addition, Onwuegbuzie, Bailey, and Daley (1999) and Casado and Dereshiwsky (2004) found the same results examining university students' language learning and language anxiety - self-confidence is the key to language learning.

In addition, the effects language anxiety has on language learning might not all be negative. Anxiety-i.e., facilitating or debilitating anxiety (Alpert \& Haber, 1960), has been shown to impact students' avoidance behavior in using the linguistic structures not present in their native languages. Because of the anxiety, this avoidance behavior affects their opportunities to learn or practice the target language. In Kleinmann's (1977) study, which employed contrastive analysis, he concluded that the ESL students experiencing facilitating anxiety did not avoid but chose to use linguistic structures not present in their native languages. On the contrary, the learners with debilitating anxiety avoided using the structures not present in their native languages. Therefore, the choice to use the linguistic structures not present in native languages might be associated with students' affective factors: the types of language anxiety (i.e., facilitating or debilitating anxiety) and self-confidence. Students' self-confidence (self-perception about one's knowledge in the target language) might affect their decisions to use or avoid linguistic structures not present in their native languages (L1s).

Self-confidence has been supported by the previous studies as a primary factor to language performance and the reduction of foreign language classroom anxiety or reading anxiety. Students' experience studying abroad or traveling to target language countries might have an effect on their self-confidence in language learning as well. The results of Matsuda and Gobel's (2004) study on the relationships among foreign language classroom anxiety, foreign language reading anxiety, and classroom performance for English-major college students in Japan, 
suggested that students' self-confidence is the key to students' success in the classroom performance. Also, students' overseas experience boosted their students' self-confidence in speaking English (low language anxiety), and therefore, lead to better classroom performance. In their study, the main factor to students' foreign language classroom anxiety and reading anxiety is self-confidence.

Self-confidence might be positively related to language proficiency and acculturation for both students from minority or majority backgrounds. In Clément's (1987) study on the relationship among Francophone university students' language status on social-psychological variables (i.e., ethno-linguistic vitality, attitudes and motivation, integrativeness, fear of assimilation, frequency or quality of contact, and acculturation) and language proficiency, he concluded that self-confidence is strongly associated with proficiency in the second language and acculturation for both majority and minority background students at the Canadian bilingual university.

Self-confidence also might have an effect on students writing and speaking in English. In Cheng, Horwitz, and Schallert's (1999) study on university students in Taiwan, the results suggested that low self-confidence is one of the primary factors causing the students' anxiety in speaking and writing in English.

In Ro's (2013) case study of an adult Korean woman, Liza, the scholar concluded that through an extensive reading (ER) treatment, Liza becomes less anxious in her reading in English (L2), and that confidence is the most significant factor in her reduction of L2 reading anxiety (p. 225). Pleasure and ease, and enjoyment in reading in L2 may have also lowered Liza's level of anxiety and increased her motivation and language achievement (Ro, 2013).

In Liu and Chen's (2013) study on Taiwanese fifth and sixth graders' foreign language anxiety and its association to multiple intelligence (MI), learning attitudes, perceived ability, and learning experience consisting of extracurricular English lessons outside class and years of learning English, the results suggested that half or more of these students experienced some level of language anxiety, and FL anxiety is significantly related to self-perceived English ability (p. 935).

In Peng and Woodrow's (2010) quantitative study on first-year and second-year non-English major Chinese undergraduates' foreign language willingness to communicate (WTC) and other variables including communication confidence and communication anxiety in China, the results suggested that students' self-confidence in communication is the most important predictor of WTC in various countries (p. 855). These two scholars stated that students who have a high level of self-confidence in FL competence and a lower level of anxiety may tend to communicate in class (p. 855).

Also, Peng and Woodrow (2010) stated that students' beliefs about what constitutes an appropriate classroom behavior also may affect students' anxiety and self-confidence (p. 856). For example, in Chinese culture, students who often speak up may be considered to be "show[ing] off" (p. 856), so these "culture-fueled beliefs" (p. 856) can have an effect on students' self-confidence (Peng \& Woodrow, 2010). In addition, Peng and Woodrow (2010) pointed out that a pleasant-atmosphere classroom environment may boost students' perceived confidence in the target language and lessen the level of anxiety (p. 857).

To sum up, based on the previous studies on language anxiety, self-confidence has a negative relationship to language anxiety (e.g., Casado \& Dereshiwsky, 2004; Cheng, Horwitz, \& Schallert, 1999; Clément, 1980; Liu \& Chen, 2013; Matsuda \& Gobel, 2004; Onwuegbuzie, Bailey, \& Daley, 1999; Peng \& Woodrow, 2010; Ro, 2013). Next, I am going to analyze the relationship between language anxiety and language identity (L2/FL), and the development of language identities.

\section{Language Ego, L2/FL Self, or Language Identity}

By representing the previous studies on L2 or FL identities, I imply that language identities and language anxiety might have some associations. Horwitz et al. (1986) noted that language anxiety is associated with the experience or emotion of feeling limited or feeling like having an L2 self while learning the target language. I believe that this emotion or experience of feeling limited or not being able to express thoughts and feelings in the target language is associated with feelings of the loss of L1 identities or the development of L2 or FL identities while learning the target language in the target language context, as shown in Figure 1. Also, language anxiety is related to self-confidence which associated with L1 and/or L2 identities as shown in Figure 1.

When speaking or writing in a L2 or FL, many learners report feeling like different people or having become different people in certain ways. For example, learners report thinking in the target language and adopting clothing or eating styles of the target language community in order to perform better in the target language or fit in better among the target language group. The concept of L2 self, language ego, or language ego boundaries to FL or L2 language learning or acquisition has been stated in the previous studies (e.g., Guiora et al., 1975; 
Guiora \& Acton, 1979; Horwitz et al., 1986). Horwitz et al. (1986) claimed that the concept of language anxiety could be a unique emotion or experience only associated with learning the target language. This anxiety (e.g., feeling like a different person or having an L2 self) is different from other anxieties associated with learning other subjects, such as physics or chemistry as Horwitz et al. (1986) pointed out. I especially agree with Horwitz et al.'s (1986) concept of the "'true' self" known by the learner (p. 31) and "limited self" in L2 (p. 31) that language learners feel limited or having another self, the L2 self, while speaking the target language. I believe that this type of emotion or experience is a part of the process of the development of L2 or FL identities; however, these language identities are limited ones-language learners may not feel like themselves or may feel like different people when speaking or writing the target language - due to the feelings of the loss of L1 identities in the L2 or FL context. Also, language anxiety arises. Learners might have experienced the anxiety while learning the target language, or they might feel anxious due to experiencing the feeling of not being themselves, feeling limited, while using the target language, such as speaking with or listening to the target language group, or writing academic papers in the target language. I believe that learning L2 or FL languages might change learners' thinking patterns and behaviors; however, their L2 or FL identities are still developing, and learners might feel incompetent or anxious in the target language environment while using or learning the target language.

However, the effects of language anxiety are not always negative. In this sociolinguistic study in Mongolia, Marzluf (2012) stated that Mongolian traditionalist fundamentalists do not view English language (FL) as a threat to their linguistic and cultural identity (L1); instead, they utilize socialist English as a "mediating role" (p. 212) to ease and express their anxieties to their neighbors such as China and other Asian countries. In other words, Mongolian fundamentalist nationalists hold little linguistic anxiety in English (Marzluf, 2012), which is facilitating anxiety as noted earlier.

Language learners' identities have been constructed or reconstructed in the process of learning the target language and are affected by the environment, culture, or society they are experiencing. According to Pierce's (1995) theory of language learners' social identity, L2 learners are negotiating their identities in the complex social world or learning context. Their social identity is constructed of or by the language they are learning and the social or cultural influences of the contexts they are in. While learning a L2, the learner experiences the construction and reconstruction of both identities-L1 identity and L2 identity. Similarly, Pavlenko (2001) reported that a L2 learner constructs and negotiates a new identity while learning a target language and participating in a target language community. Likewise, Scollon (1997) stated the relationship between an ESL student's life experiences of learning English (speaking, writing, and reading English), his/her original culture, language, society, and the student's language writing in the target language community, form a continua (p. 353) This continua represents L2 students' life experiences learning English (the influence of popular culture, including media, TV, and videos), their native languages and the constant changing and developing identities.

Other concepts of language identity such as language ego or permeability of language ego boundaries also explain what language identity is and how language learners feel or react to these changing identities, while learning a new language. Guiora et al. (1975) introduced the concept of language ego, which is similar to the concept of body ego. They assumed that "language ego is a maturational concept and likewise refers to self-representation with physical outlines and firm boundaries" (p. 45). Guiora and Acton (1979) claimed that the concept of "permeability of language ego boundaries" (p. 199) refers to language learners' ability to "move back and forth between languages" (p. 199) and the switch of the "personalities" (p. 199) that seem to come from the immersion of the target language. This idea is similar to the common agreement that a language learner "feels like a different person" (p. 199) when speaking a L2 or FL and often acts somehow differently as well.

In Cervatiuc (2009)'s qualitative study on twenty successful adult advanced non-native speaker (NNS) immigrants' identity construction and language learning in Canada, one of the participants, Adi, claimed that he built his self-confidence including his language ability proficiency by affirming to himself that he speaks more than one language, how much he has achieved, and that native speakers (NS) - who are only monolingual—also make grammar mistakes. Some of Cervatiuc's (2009) participants claimed that they felt the urgency to go to "the extreme" (p. 261) to start conversations with local community members to become extroverted in order to practice the target language (L2) due to the fact that they were not naturally extroverted (p. 261), which illustrates that the participants feel like another person or change their personalities during the process of L2 identity developing or L1 reconstruction. I believe that this concept is also similar to the concept of contrastive rhetoric and in the sense that it indicates that a language learner's L2 or FL identity is developing or L1 (old) language identity is being reconstructed or changing while learning a new language. 


\subsection{Thought Pattern and L2 or FL Self}

In accordance with this concept of contrastive rhetoric, over time, the learner's logic of thought may change due to learning the target language; therefore, their identities might evolve as well; however, I believe their L2 or FL identities are developing while learning the target language, and their native language identities (L1) are limited, or language learners feel broken in the target language context. This concept can be supported by Cervatiuc's (2009) study in Canada. One participant in the study, Veronica, stated that "[e]ven if I keep my first language identity [L1 identity], I would still say that I am at least 50 percent Canadian" (Cervatiuc, 2009, p. 263). The other participant, Bojana, revealed that "after the 5 years that I spent in Canada, I thought that I was living on an island, neither here, nor there" (p. 264). In Cervatiuc's (2009) study, many participants claimed that they experienced "temporary alienation, loss of identity or perceived marginalization" (p. 264) as L2 or NNS speakers in Canada, which represents that these participants felt temporarily broken or limited in L1. Kaplan (1966) wrote, "[t]he foreign student who has mastered the syntax of English may still write a bad paragraph or a bad paper unless he also masters the logic of English" (p. 15). The concept of contrastive rhetoric assumes that languages are different, not only in phonology, morphology, and grammar, but also in genres and rhetorical and syntactic features (Kaplan, 2001, p. viii). Therefore, while learning a new language, a student's L2 or FL identity in the new language and culture may be developing or his or her L1 identity may be reconstructed or may be changing because a learner may need to adapt the logic of thought/cultural-thought patterns or rhetorical structures of his or her native language to that of the target language (to learn to think in the target language) in order to write a good essay in the target language. For example, a Chinese writer's rhetorical structures and thought patterns may be generally indirect, while in English may be generally direct. In Chinese writing or speaking, the speaker or writer usually points out the main idea at the end. On the contrary, based on the academic writing or speaking conventions in English, writers should state their theses at the beginning, usually in the introduction. In my own personal experience, I have to consciously think about what my thesis statement is when writing an English composition and revise my thesis many times because in Chinese writing the main point appears at the end, and my mind automatically thinks in this fashion. For instance, Shen (1998) reported that he developed a combined identity, including his old and new identities (Chinese self and English self), in his English composition, and he stated that identity is a key to learning how to write a good English composition. Another example is in Benson, Barkhuizen, Bodycott, and Brown's (2012) qualitative study on nine undergraduate students in a pre-service teacher education program from Hong Kong participating in the study abroad program. One participant, Anna, reported that she forced herself to speak in English from the beginning of her stay in Canada in order to make friends with the target language speakers, which shows that she might have the self-confidence to speak English or in her English speaking ability. She reported that she is then able to think and communicate in English because she wants to be like a native speaker (L2 identity developing) in the hopes of becoming "one of them" (p. 185) one day. Anna's motivation to think in English (L2) is a good example of logic of thought patterns in L2. Nevertheless, language learners' identities in the new language are developing because they may feel like different people (having L2 selves), feel limited, broken, or incomplete when they have difficulties functioning in the target language such as speaking, listening, reading, or writing, and they may feel that they cannot deliver their thoughts or ideas in a clear way the same as using their native languages (L1s). In the meantime, they might also experience language anxiety due to experiencing a sense of incapability in the target language (e.g., low self-confidence).

As mentioned earlier, the logic of thought/cultural thought patterns (i.e., the concept of contrastive rhetoric) in the native language may interfere with performance in the target language. For example, when I write an academic English paper, I will unconsciously use the rhetorical structure of Chinese. In Silva's (1993) study of thirteen ESL international graduate students' perceptions on the differences between L1 and L2 writing, some of the participants suggested that they think primarily in L1 and then translate L1 to L2 when writing English papers. Some expressed that the rhetorical structure, directness, makes writing an English paper difficult or frequently confuses their American instructors because in the student's culture or rhetorical conventions are generally indirect. Most of the participants in Silva's (1993) study commented that their native languages interfere with English writing, and their concepts of audience, rhetoric, vocabulary, or grammar are limited; therefore, they found themselves unable to express their thoughts and intentions when writing in a target language. Their target language identities are developing while learning the target language; however, their logic of thought may still come from their native languages (L1s). Their expressions in the target language are limited due to the incompetence of the new language and the thinking patterns in their native languages (L1s). 


\subsection{Changes of L1 Self and Development of L2 Self}

L2 or FL students' language identities might be constantly developing while learning new languages. The following previous studies seem to support the concept of changes of L1 self and development of L2 identity. However, I believe that a learner's native identity (L1 self) may be broken or limited while functioning in the target language in the target language context. In Eva Hoffman's Lost in Translation, the goal of her writing journals in her L2, English, is to develop a new thinking model for her daily life in that language (Watkins-Goffman, 2001, p. 32). During that time, she was developing a thinking mode in English, and she found a new self in the U.S., which was her new identity in English. In Richard Rodriguez's work, Hunger of Memory, he lost his native language, and in the process he mastered the target language, English (L2) and obtained a new identity in English (Watkins-Goffman, 2001, p. 20); however, after he succeeded in the L2 society, he missed his old identity and language in Spanish (L1). In Julia Alvarez's Something to Declare, she was searching for her identity in the U.S., and during this process, she affirmed her old identity (Watkins-Goffman, 2001, p. 44). I have had experiences like Alvarez, where a language learner is searching for his or her identity in a new country.

Spack (1997) reported on a case study conducted by Tucker. When she read the essay of a student named Najla, she thought the writing was the product of the rhetorical tradition of Najla's native culture, Afghani (p. 772). After she interviewed her, she realized that when the student wrote the essay, she imitated the rhetorical features found in the readings she was fond of, which were the U.S. and Pakistan. Najla's identity as a writer was still developing multi-culturally, not only in relation to the U.S. but also in other cultures. Tucker cautioned that when reading a student's writing, teachers should take into account a student's cross-border culture and still-evolving identities, and the fact that a student may not merely be the product of a culture or their native culture, but also the creator of a culture. Najla's identity in her writing may be the combination of her old culture and language, Afghani, and her new culture and new language in the U.S. or another culture. As mentioned earlier, I believe that Najla's identity in the target language writing (L2 self) is still developing. Also, her identity (L1 self) is recreated or reconstructed based on the cultures and languages she is learning and the environment she is experiencing.

Language learners' identities have been changing through the processes of language learning in multiple target language settings. In Haneda's (2005) case studies on two adult students from two different backgrounds and enrolled in her Japanese literacy classes at a Canadian university, she concluded that these two participants had invested themselves in the Japanese learning, and through their previous or present membership or participation in the classroom or several target language communities, their L1 identities had been changing.

By examining English-speaking German students' essays focusing on language choice, Belz (2002) concluded that through the creation of new form or combination of their native languages and German or other languages, they gain control of the new language and express themselves in sense of who they are and show how they interact themselves with the world (i.e., their identities). These adult L2 learners have experienced changes of their identities by learning the L2 and representing their changing selves in the text (i.e., language names, syntactic play) they create. For them, learning a new language is for self-improvement, so through and in the process of learning a new language, they identify themselves as multi-competent instead of as having an L2 deficiency. Therefore, this changes their self-conceptualizations, which are represented in their text as their textual identities. I can predict, in this case, due to the fact that they are learning a new language for self-improvement, so language anxiety may be avoided or reduced.

By analyzing the collection of their language learning autobiographical narratives, Lin, Wang, Akamatsu, and Mehdi (2002) expressed how they invested themselves in learning English, and how their identities and their lives have changed in the process of learning the new language. One of the authors, Wang, stated in her language learning autobiography that by using the Chinese and English in class with teachers and classmates, they created a world for themselves: "Chinese was the language to represent ourselves" (p. 302) (i.e., L1 identity) and English is the language for us (i.e., the development of L2 identity) "to expand who we were and who we wanted to be" (Lin et al., 2002, p. 302). English became the "language of dream" (p. 302) and freedom and liberated her psychologically. For another author, Lin, learning English expanded and enriched her social and cultural worlds by having pen-pals all around the world, and she gradually created her inner-self in English (the development of L2 identity) by writing English diaries to improve her English. She later realized that writing in English liberated her thoughts, and she could easily write what she felt in her English diaries. She expressed in her autobiography, "...I seemed to have found a tool that gave me more freedom to express my innermost fears, worries, anger, conflicts..." (Lin et al., 2002, p. 303). 
Based on Belz's (2002) and Lin et al.'s (2002) studies shown above, the participants' L2 or FL identities were created according to learners' life experiences, cultures, or societies in which they take part and based on their motivation or purpose for learning a new language, such as for self-improvement or to be someone else.

In Chen's (2010) research on a Chinese fourth grade boy named Evan, the results suggested that Evan was negotiating with multiple identities or having identity conflicts as an ELL student (i.e., low status or a undesirable L2 identity, low self-confidence) or a smart math student in an advanced Math class (i.e., desirable high status, high self-confidence). Evan is developing his L2 identity. In regular classes or advanced Math classes, he was fortunate that his teachers view his native language, Chinese, as a resource for his learning in school (high status in L1). However, Evan's lack of resources in English (English proficiency and communication norms) caused him to physically fight with peers he felt teased or made fun of by because he felt limited in his L2 (Chen, 2010, p. 176).

In Cervatiuc's (2009) study, these successful advanced NNS immigrants felt the need to act native in Canadian corporate culture in order to fit in; however, in the beginning of the process, they perceived this is "an attack on their L1 identity and a high price to pay" (p. 263) for their employment success, which illustrates feeling broken in L1self. Also, these participants indicated that they might never be considered a true member of the target (NS) community. These participants admitted that they felt torn between these two cultures, L1 and L2 cultures, for many years, and they finally stopped regarding their L1 and L2 identities as "conflicting and disharmonious" (p. 263), which shows that their L1 identities being reconstructed in the process.

Moreover, Cervatiuc (2009) stated that after many years residing in Canada, these advanced NNS participants feel close to both their L1 and L2 communities; nevertheless, they do not view themselves as "entirely true Canadians" (p. 265), and they still view themselves in their L1 identities. Therefore, the majority of these participants view themselves as possessing a combination of L1 and L2 identities (p. 264). For example, one of these participants, Bojana, stated, "I have a hyphenated identity, as I consider myself to be a Canadian-Serbian" (Cervatiuc, 2009, p. 264).

In Benson et al.'s (2012) study, one participant, Sally, claimed that the more development in her L2 speaking and listening, the more self-confidence in using L2 she gained, and this improved self-confidence is associated with her L2 identity development because she could see herself as a language "user" (p. 185) instead of "learner" (p. 185), and learning the L2 is by the process of using it rather than just studying grammar and vocabulary (Benson et al., 2012).

Of the participants in Benson et al.'s (2009) study, Joey, claimed that she can normally communicate with Australians, and she saw herself as an "almost native speaker" (p. 187); however, as a Chinese female (L1 identity), she pointed out, she was harassed and racially discriminated in Australia, which shows that her L1 identity is broken, and in this process she reported that she had a stronger Chinese identity (L1 self), which represents L1 reconstruction. Finally, Janice who also studied abroad in Australia, commented that even though she married a native speaker, she will never be a native speaker, and she claimed that she also identifies herself as Chinese (L1 self) (Benson et al., 2012, p. 187).

\subsection{Development of FL Self}

The developing of FL self has also appeared in the previous literature (e.g., Benson et al., 2012; Khodadady \& Navari, 2012; Shin, 2010). In Shin's (2010) qualitative study on twelve adults of mixed heritage backgrounds with one English-speaking parent and one immigrant parent who speaks another ethnic language, one of the participants, Julie, is half Japanese and half White, but she claimed that she never learned to speak Japanese growing up due to her mother, who never spoke to her in Japanese. She then determined to learn to speak Japanese in order to be Japanese in order to form her foreign language identity (FL) or heritage language identity (HL). The other participant in Shin's (2010) study, Suzanne, claimed that she does not view herself as Chinese (FL or HL identity) because she cannot speak Cantonese. Suzanne's father is Cantonese native speaker but was reluctant to teach her the language. Due to the difficulties of learning Cantonese as an adult, she decided to learn Italian instead to feel "something other than just American" (Shin, 2010, p. 214) because "[i]t's kind of maybe my [her] way of compensating" (Shin, 2010, p. 214). In this process, Suzanne is developing her FL identity in Italian.

In Khodadady and Navari's (2012) quantitative research on a mix of high-school, college, graduate-level female advanced English learners' FL identity and English learning with different disciplines in Iran, the results suggested that based on the learners' educational level, high-school, college, and the learners who plan to study abroad, their English (FL) helps them establish their idealized FL identity. 
In Benson et al.'s (2012) study, one of the participants, Selina, stated that after working in the university's International Office in UK, and then returning to Hong Kong, she finally believed that she has achieved English proficiency (i.e., self-confidence). She reported to be able to utilize the FL to make friends with students from overseas in Hong Kong.

In this same study, Ruby, stated that after returning from the UK, she tended to say "hello" (p. 187) and "thank you" (p. 187) in English (FL) to bus drivers which is not a common practice in Hong Kong, which is another example of the development of FL self or feeling like another person (Benson et al., 2009).

In brief, these immigrants or L2 or FL learners reported their emotions toward learning L2 or FL, their experiences, and how these experiences affected their L1 identities and the development of their L2 or FL identities, which supports the concept of L1 self or L2/FL self in a language context shown in Figure 1.

\section{Conclusion}

In summary, based on the previous literature, language learners' self-confidence (or language selves/language identities) is related to language anxiety experienced during the process of learning in the target language communities or academic settings. Self-confidence may lower learners' levels of language anxiety and enhance language achievement or performance. While learning the target language, this unique experience or emotion (e.g., feeling like a different person, feeling like having an L2 or FL self, or feeling limited) implies that language anxiety is associated with language learners' development of L2 or FL selves or identities or the emotion of feeling incompetent, limited, or broken in the target language, compared to being in the L1 environment where they are able to express their thoughts easily and clearly. Language learners might develop $\mathrm{L} 2$ or FL identities or the combination of L1 and L2/FL identities through learning the target language in academic settings or target language communities. However, language learners' anxiety about not being able to function well in the target language makes them feel incompetent (a sense of low self-confident), limited, or due to the difficulties in the target language (i.e., L2 or FL), and being unable to communicate in their native languages (L1) to a target language group, they do not feel like themselves anymore (i.e., the feeling of the loss of L1 identity). For example, when they speak their native languages, they feel like themselves. In comparison to in L2 or FL contexts, they know who they are and what they want to say in their native languages (L1)-i.e., the feeling of the loss of L1 identity while speaking the target language (L2 or FL) in the target language context. This problem implies that in the process of the development of L2 or FL identities or the reconstruction of L1 (old) identities, language learners might feel limited or do not feel like themselves, and language anxiety arises. They might have experienced language anxiety while learning the target language, or due to not being able to express their feelings or thoughts or function well in the target language, they may start to experience this anxiety. 


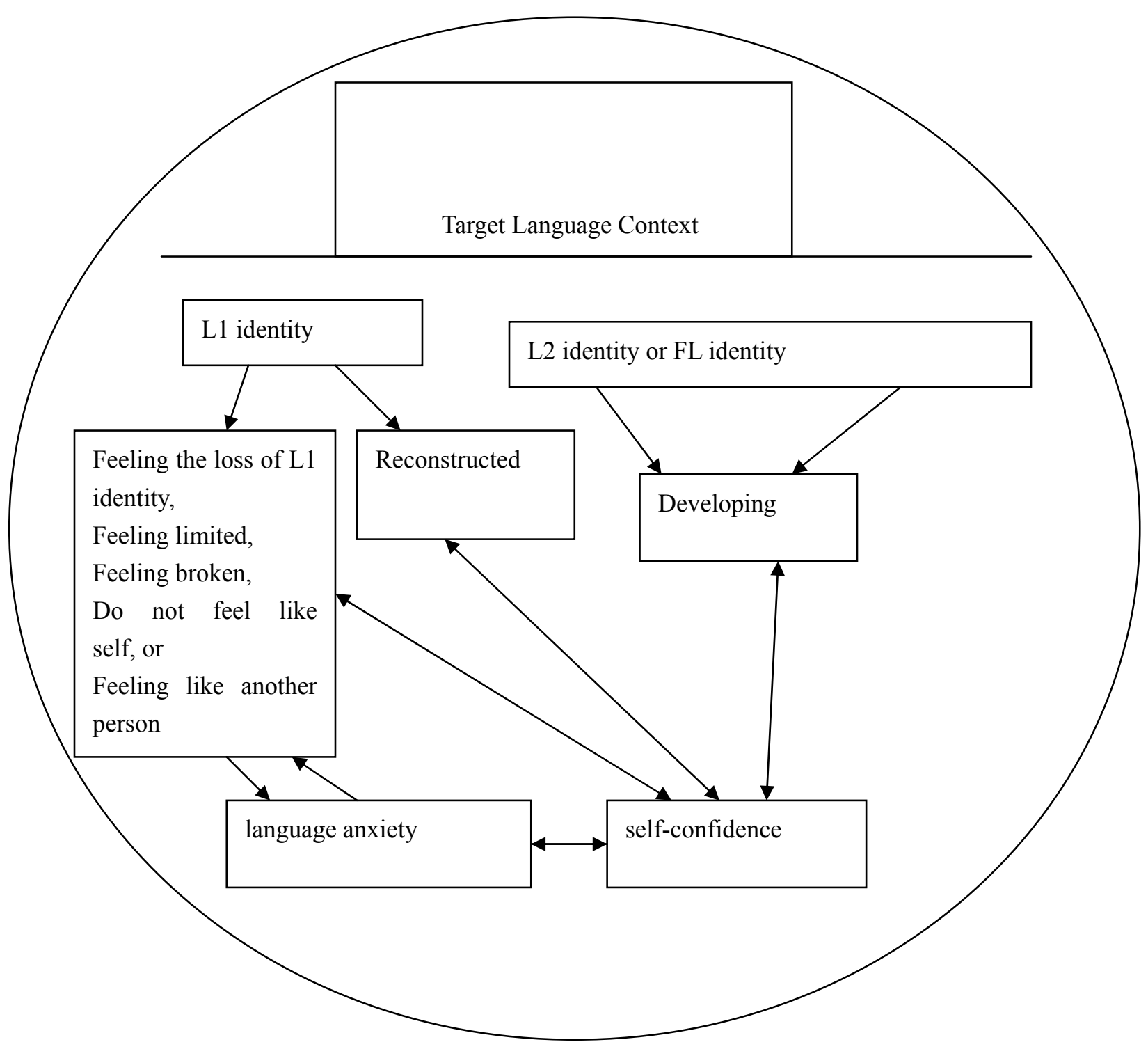

Figure 1. Relationship among language anxiety, self-confidence, and language identity in a target language context

\section{References}

Alpert, R., \& Haber, R. (1960). Anxiety in academic achievement situations. Journal of Abnormal and Social Psychology, 61, 207-215. http://dx.doi.org/10.1037/h0045464

Aydın, B., \& Gönen, İ. (2012). Listening to Students: Modification of a Reading Program Based on the Sources of Foreign Language Reading Anxiety. Turkish Online Journal of Qualitative Inquiry, 3(1), 20-35.

Belz, J. A. (2002). Second language play as a representation of the multicompetent self in foreign language study. Journal of Language, Identity, \& Education, 1(1), 13-39. http://dx.doi.org/10.1207/S15327701JLIE0101_3

Benson, P., Barkhuizen, G., Bodycott, P., \& Brown, J. (2012). Study abroad and the development of second $\begin{array}{lllll}\text { language identities. } & \text { Applied }\end{array}$ http://dx.doi.org/10.1515/applirev-2012-0008

Casado, M. A., \& Dereshiwsky, M. I. (2004, March). Effect of educational strategies on anxiety in the second language classroom: An exploratory comparative study between U. S. and Spanish first-semester university students. College Student Journal, 38(1), 23-36.

Cervatiuc, A. (2009). Identity, Good Language Learning, and Adult Immigrants in Canada. Journal of Language, 
Identity \& Education, 8(4), 254-271. http://dx.doi.org/10.1080/15348450903130439

Chang, A. (2008). Sources of listening anxiety in learning English as a foreign language. Perceptual \& Motor Skills, 106(1), 21-34. http://dx.doi.org/10.2466/pms.106.1.21-34

Chen, X. (2010). Identity Construction and Negotiation Within and Across School Communities: The Case of One English-as-a-New-Language (ENL) Student. Journal of Language, Identity \& Education, 9(3), 163-179. http://dx.doi.org/10.1080/15348458.2010.486274

Cheng, Y., Horwitz, E. K., \& Schallert, D. L. (1999). Language anxiety: Differentiating writing and speaking components. Language Learning, 49(3), 417-446. http://dx.doi.org/10.1111/0023-8333.00095

Clément, R. (1980). Ethnicity, contact, and communicative competence in a second language. In H. Giles, W. P. Robinson, \& P. M. Smith (Eds.), Language: Social psychological perspectives (pp. 147-154). Oxford: Pergamon.

Clément, R. (1987). Second language proficiency and acculturation: An investigation of the effects of language status and individual characteristics. Journal of Language and Social Psychology, 5, 271-290. http://dx.doi.org/10.1177/0261927X8600500403

Daly, J. A., Caughlin, J. P., \& Stafford, L. (1997). Correlates and consequences of social-communicative anxiety. In J. A. Daly, J. C. McCroskey, J. Ayres, T. Hopf, \& D. M. Ayres (Eds.), Avoiding communication: Shyness, reticence, and communication apprehension (2nd ed., pp. 21-71). Cresskill, NJ: Hampton Press.

Ehrman, M. E., \& Oxford, R. L. (1995). Cognition plus: Correlates of language learning success. The Modern Journal, 79(1), 67-89.

Eunseok, R. (2013). A case study of extensive reading with an unmotivated L2 reader. Reading In A Foreign Language, 25(2), 213-233.

Guiora, A. Z., \& Acton, W. R. (1979). Personality and language behavior: a restatement. Language Learning, 29(1), 193-204. http://dx.doi.org/10.1111/j.1467-1770.1979.tb01059.x

Guiora, A. Z., Paluszny, M., Beit-Hallahmi, B., Catford, J. C., Colley, R. E., \& Dull, C. Y. (1975). Language and person: Studies in language behavior. Language Learning, 25(1), 43-61. http://dx.doi.org/10.1111/j.1467-1770.1975.tb00108.x

Haneda, M. (2005). Investing in foreign-language writing: A study of two multicultural Learners. Journal of Language, Identity, \& Education, 4(4), 269-290. http://dx.doi.org/10.1207/s15327701jlie0404_2

Horwitz, E, K., Horwitz, M. B., \& Cope, J. A. (1986). Foreign language classroom anxiety. In E. K. Horwitz, \& D. J. Young (Eds.), Language anxiety: From theory and research to classroom implications (pp. 27-36). Englewood Cliffs, NJ: Prentice-Hill.

Kaplan, R. B. (1966). Cultural-thought patterns in inter-cultural education. Language Learning, 16, 1-20. http://dx.doi.org/10.1111/j.1467-1770.1966.tb00804.x

Kaplan, R. B. (2001). Forward: What in the world is contrastive rhetoric? In C. G. Panetta (Ed.), Contrastive rhetoric revisited and redefined (pp. vii-xx). Mahwah, NJ: Lawrence Erlbaum.

Khodadady, E., \& Navari, S. (2012). Foreign language identity and its relationship with travelling and educational level. English language Teaching, 5(3), 30-39. http://dx.doi.org/10.5539/elt.v5n3p30

Kleinmann, H. H. (1977). Avoidance behavior in adult second language acquisition. Language Learning, 27(1), 93-107. http://dx.doi.org/10.1111/j.1467-1770.1977.tb00294.x

Leki, I. (1999). Techniques for reducing second language writing anxiety. In D. J. Young (Ed.), Affect in foreign language and second language learning: A practical guide to creating a low-anxiety classroom atmosphere (pp. 64-88). Boston, MA: McGraw-Hill.

Lin, A., Wang, W., Akamatsu, N., \& Mehdi, R. A. (2002). Appropriating English, expanding identities, and re-visioning the field: From TESOL to teaching English for globalized communication (TEGCOM). Journal of Identity, Language, \& Education, 1(4), 295-316.

Liu, H.-J., \& Chen, T.-H. (2013). Foreign Language Anxiety in Young Learners: How It Relates to Multiple Intelligences, Learner Attitudes, and Perceived Competence. Journal of Language Teaching \& Research, 4(5), 932-938. http://dx.doi.org/10.4304/jltr.4.5.932-938

MacIntyre, P. D. (1995). How does anxiety affect second language learning? A reply to Sparks and Ganschow. The Modern Language Journal, 79(1), 90-99. http://dx.doi.org/10.1111/j.1540-4781.1995.tb05418.x 
MacIntyre, P. D., \& Gardner, R. C. (1991, March). Methods and results in the study of anxiety and language learning: A review of the literature. Language Learning, 41(1), 85-117. http://dx.doi.org/10.1111/j.1467-1770.1991.tb00677.x

Markus, H. R., \& Kitayama, S. K. (1991). Culture and the self: Implications for cognition, emotion, and motivation. Psychological Review, 98(2), 224-253. http://dx.doi.org/10.1037/0033-295X.98.2.224

Marzluf, P. (2012). Words, borders, herds: Post-socialist English and nationalist language identities in Mongolia. International Journal of the Sociology of Language, 2012(218), 195-216.

Matsuda, S., \& Gobel, P. (2004). Anxiety and predictors of performance in the foreign language classroom. System, 32, 21-36. http://dx.doi.org/10.1016/j.system.2003.08.002

Onwuegbuzie, A. J., Bailey, P., \& Daley, C. E. (1999). Factors associated with foreign language anxiety. Applied Psycholinguistics, 20, 217-239. http://dx.doi.org/10.1017/S0142716499002039

Onwuegbuzie, A. J., Bailey, P., \& Daley, C. E. (2000, September/October). Cognitive, affective, personality, and demographic predictors of foreign-language achievement. The Journal of Educational Research, 94(1), 3-15. http://dx.doi.org/10.1080/00220670009598738

Öztürk, G., \& Gürbüz, N. (2014). Speaking anxiety among Turkish EFL learners: The case at a state university. Journal of Language \& Linguistics Studies, 10(1), 1-17.

Pappamihiel, N. E. (2002, February). English as a second language students and English language anxiety: Issues in the mainstream classroom. Research in the Teaching of English, 36, 327-355.

Pavlenko, A. (2001). In the world of the tradition, I was unimagined: Negotiation of identities in cross-cultural autobiographies. The International Journal of Bilingualism, 5(3), 317-344. http://dx.doi.org/10.1177/13670069010050030401

Peng, J., \& Woodrow, L. (2010). Willingness to Communicate in English: A Model in the Chinese EFL $\begin{array}{lllll}\text { Classroom Context. } & \text { Language }\end{array}$ http://dx.doi.org/10.1111/j.1467-9922.2010.00576.x

Pierce, B. N. (1995). Social identity, investment, and language learning. TESOL Quarterly, 29(1), 9-31. http://dx.doi.org/10.2307/3587803

Scollon, R. (1997). Contrastive rhetoric, contrastive poetics, or perhaps something else? TESOL Quarterly, 31(2), 352-358. http://dx.doi.org/10.2307/3588051

Scullin, B. L., \& Baron, H. (2013). Using Freewriting Notebooks to Reduce Writing Anxiety for English Language Learners. California Reader, 47(1), 19-26.

Selltiz, C., Christ, J. R., Havel, J., \& Cook, S. W. (1963). Attitudes and social relations of foreign students in the Unites States. Minneapolis, MN: Lund Press.

Shen, F. (1998). The classroom and the wider culture: identity as a key to learning English composition. In V. Zamel, \& R. Spack (Eds.), Negotiating academic literacies (pp. 123-133). Mahwah, NJ: Erlbaum.

Shin, S. J. (2010). "What About Me? I'm Not Like Chinese But I'm Not Like American”: Heritage-Language Learning and Identity of Mixed-Heritage Adults. Journal of Language, Identity \& Education, 9(3), 203-219. http://dx.doi.org/10.1080/15348458.2010.486277

Silva, T. (1993, Fall). L1 vs L2 writing; ESL graduate students' perceptions. TESL Canada Journal, 10(1), 27-47.

Spack, R. (1997). The rhetorical construction of multilingual students. TESOL Quarterly, 31(4), 765-774. http://dx.doi.org/10.2307/3587759

Vogely, A. (1999). Addressing listening comprehension anxiety. In D. J. Young (Ed.), Affect in foreign language and second language learning: A practical guide to creating a low-anxiety classroom atmosphere (pp. 106-123). USA: McGraw-Hill.

Watkins-Goffman, L. (2001). Lives in two languages: An exploration of identity and culture. USA: University Michigan Press.

Woodrow, L. (2006). Anxiety and speaking English as a second language. RELC Journal, 37, 308-328. http://dx.doi.org/10.1177/0033688206071315 


\section{Copyrights}

Copyright for this article is retained by the author(s), with first publication rights granted to the journal.

This is an open-access article distributed under the terms and conditions of the Creative Commons Attribution license (http://creativecommons.org/licenses/by/3.0/). 